\title{
LA «EPÍSTOLA A LA SEÑORA DE LEOPOLDO LUGONES»DE RUBÉN DARÍO, DESMITIFICACIÓN POÉTICA DEL MODERNISMO
}

\author{
CARMEN RUIZ BARRIONUEVO \\ Universidad de Salamanca
}

\section{Resumen}

La «Epístola A la señora de Leopoldo Lugones», que aparece incluida en El canto errante (1907), es una obra que evidencia la maestría poética de Rubén Darío. Distribuida en siete apartados no puede entenderse sin el contexto biográfico del autor y su necesidad de realizar unas confidencias irónicas acerca de su propia vida inserta en el proceso de modernización del siglo Xx. Por ello se propone un análisis de sus apartados y su disposición atendiendo a desvelar todas las referencias geográficas y vitales que recorren dos continentes para recalar en la isla de Mallorca. Se atiende también a la estructura métrica del poema que parte de la utilización del verso alejandrino para convertirlo en vehículo de una poesía dialogante y conversacional que sin duda representa una transición hacia la poesía posterior.

Palabras clave: Poesía modernista; Rubén Darío; El canto errante; Epístola A la señora de Leopoldo Lugones.

\begin{abstract}
The "Epístola A la señora de Leopoldo Lugones", included in El canto errante (1907) proves the poetic mastery of Ruben Dario. It cannot be understood without Darío's biographical context, and his need for an ironic voice to make confidences about his own life, whilst paying attention to the modernization of the early twentieth century. We propose a separated analysis of each one of its sections, and we aim to disclose all the geographical and vital references that cross two continents and anchor on the island of Mallorca. The author uses a metric structure based on Alexandrine verses to turn the poem into a dialogue and ca onversational artifact that undoubtedly represents a transition to the later poetry.
\end{abstract}


Keywords: Modernist poetry; Rubén Darío; El canto errante; «Epístola A la señora de Leopoldo Lugones».

No es Rubén Darío poeta de muchos poemas largos, uno de ellos es la sorprendente «Epístola A la señora de Leopoldo Lugones» que da muestra de su maestría como poeta en la trayectoria final de su vida. Incluida en ese libro un tanto misceláneo que es El canto errante (1907), sin embargo contó con una versión más larga que fue publicada el 7 de enero de ese mismo año en los Lunes de El Imparcial de Madrid, de cuyo texto suprimió 18 versos. Aunque esta omisión no afecta en demasía a la versión definitiva, sin embargo tiene interés para la interpretación completa del poema. En su día Enrique Díez Canedo llamó la atención sobre este hecho y abogó por la inclusión de estos versos en una edición de las obras completas (1944: 92-95). En cualquier caso, al redactar su obra el poeta no solo escribe una «epístola», rompiendo el molde clásico y actualizándolo, sino que introduce novedades sustanciales en el plano de la forma, al usar de la ironía en una especie de autoexploración vital en la que vuelca su biografía; un elemento que en la última parte del modernismo fractura la placidez de las formas estéticas del movimiento para alcanzar la transición a la vanguardia. Y todo ello trabajando el verso más emblemático del modernismo, el alejandrino, que sin embargo se plasma en un poema de una especial confidencia irónica que preludia la poesía conversacional de las décadas posteriores en la época posvanguardista.

\section{Contexto de la escritura, la biografía y el acervo cultural}

Escrita en 1906, está situada en diferentes momentos de ese año, en Anvers (Amberes), Buenos Aires, París y Palma de Mallorca. Resulta claro que a través del texto Rubén Darío establecía un diálogo con el poeta Leopoldo Lugones (1874-1938) con el que le unía gran amistad desde sus años bonaerenses (Carilla, 1967: 123-142), y sin embargo, para establecer ese diálogo utiliza a la esposa de su amigo, Juana González de Lugones, como destinataria de la carta. Pero, como ya he podido demostrar en otro lado (Ruiz Barrionuevo, 1997:109) parece seguro que con su epístola Darío respondía a otra epístola de su amigo, titulada «A Rubén Darío» ${ }^{1}$, aparecida en Athenas de Córdoba (Argentina) el 8 de enero de 1903 (Lugones, 1959: 1160-1162), en la que le hacía algunas confidencias personales y amistosas para comunicarle el nacimiento de su hijo,

1. La composición se publica en 1903 aunque pueda datar de 1897, año del nacimiento de único hijo de Lugones, cuyo tema ocupa la mitad de los versos. 
e incluso lo emuló al seguir la misma forma métrica, pues ambos poemas son cartas que usan la misma forma, el alejandrino pareado. Es cierto que en la comparación de los dos poemas, el de Lugones resulta menos logrado que el del nicaragüense, aunque los dos practiquen el diálogo a través de los versos con un tono coloquial y hasta humorístico con alusiones e insinuaciones varias a sus respectivas trayectorias, e incluso introduciendo anécdotas veladas que hay que leer al hilo del texto que Darío escribió al poco de conocerlo, «Un poeta socialista, Leopoldo Lugones», que dedicó al joven cordobés en 1896 en el periódico El Tiempo de Buenos Aires (recopilado en Gullón, 1980: 203). Este y otros testimonios abundan en la amistad que existió entre los dos poetas y que la epístola de Darío a la señora de Leopoldo Lugones también testimonia.

El poema (Darío, 1977: 344-49) tiene una distribución muy certera, pues consta de siete partes desiguales que se corresponden con unos momentos vitales sucesivos, de las cuales la última es tan solo un breve cierre de seis versos. Si revisamos la estructura del poema se observa que en realidad son seis apartados que revisan su propio itinerario biográfico, con lo que se coloca a si mismo en el propio centro como sujeto poético. De este modo los tres primeros apartados son eco de su vida viajera por dos continentes, y los tres últimos, son expresión de su recuperación y convalecencia en la isla de Mallorca. Encontramos así una clara oposición entre los seis apartados que en realidad constituyen el poema, los tres primeros se caracterizan por su dinamismo y por la incisiva ironía acerca del mundo moderno; en ellos el Darío de los últimos años vuelca su experiencia viajera y la saturación de su vida inserta en la modernidad. En cambio, en los tres últimos apartados el sujeto poético encuentra el reposo de la isla paradisíaca en la que la serenidad contrasta con la febril actividad desarrollada en tres apartados precedentes.

Darío recoge la tradición de la epístola y la remodela, de tal modo que soslaya los condicionamientos clásicos de este tipo de poemas para centrar el desarrollo en el trascurrir de la propia vida, sin embargo hay elementos que continúan la tradición, como el tono confidencial al contar sus experiencias y la inserción de algunos elementos retóricos, como la original salutatio que da inicio a la primera parte y que contiene el nombre de la destinataria en dos versos que evocan el recuerdo de Amberes y de Rodenbach («Madame Lugones, J'ai commencé ces vers / en écoutant la voix d'un carillon d'Anvers..».). El escritor belga, Georges Rodenbach (1855-1898) era conocido por su obra poética y sobre todo por un título que fascinó en su época, Brujas la muerta $(1892)^{2}$, pero aquí sin duda la inclusión de su apellido es un juego con

2. Víctor Valembois al estudiar la presencia de la geografía y de los autores belgas en la obra de Rubén Darío indica que «Puede haberlo conocido personalmente, pero no hay 
un autor que admiraba y cuyo nombre propicia la rima de los dos pareados, los dos primeros en francés y los otros dos en una rima extraña en español (Rodenbach, Bach) lo que lleva implícita la sorpresa, el cambio de perspectiva que se introduce en el comienzo del itinerario para proyectar el dinamismo del vivir y la mudanza de continente. Notemos que se dirige a la destinataria en francés, idioma que conocía, escrito o hablado, la clase intelectual de su época, lo que introducía también la confianza y hasta la broma establecida. Con todo, hay que tener en cuenta, que como en toda epístola, el autor trata de desgranar el paso de la vida, cuyo itinerario en este caso es la errancia inserta en el vivir del poeta moderno, un dinamismo expreso en los puntos suspensivos: «iAsí empecé, en francés, pensando en Rodenbach / cuando hice hacia Brasil una fuga... de Bach!». El tono admirativo de los versos que se configura como jocoso y esa palabra, fuga, es justamente la que marcará las tres primeras partes del poema. Se advierte además que estos cuatro versos son el pórtico o la introducción a cuanto se va a desgranar a partir de ahora, en realidad esos versos nos abren la confidencia que toda carta implica.

Los 18 versos de la primera parte y los 29 de la segunda hacen alusión a sus vivencias en Río de Janeiro adonde acudió como secretario de la Delegación nicaragüense para participar en la III Conferencia Panamericana (Darío, 1950: 343-354). Sin hacer alusión directa a su misión política, Darío prefiere introducir imágenes que hacen referencia irónica a su obra creativa de poeta en una recurrencia metapoética, «En Río de Janeiro iba yo a proseguir, / poniendo en cada verso el oro y el zafir», pero las imágenes mezclan de forma caótica las impresiones que proceden de distintos ámbitos, «el oro y el zafir», «la esmeralda de esos pájaros-moscas», «áureas siestas foscas», «cruel vómito negro», «fiebre amarilla». Imágenes que son interrumpidas por acotaciones conversacionales: « $¡$ Me alegro! e incluso con expresiones francesas: «Et pour cause». Cuando introduce la referencia al encargo que le llevaba a Brasil aparece una confesión irónica expresada en una frase que se ha convertido en paradigma de su escasa disposición para la actividad diplomática: «Yo panamericanicé / con un vago temor y con muy poca fe». En contraste, los versos se cargan de imágenes que sugiere el entorno brasileño y que expresan la cordialidad de la gente, el gozo de la vida, el calor y la sensualidad del trópico: «Me encantó ver la vera machicha», baile popular brasileño que se puso de moda en Europa a comienzos de siglo. Los puntos suspensivos al final de la enumeración apelan a la imaginación de la interlocutora para pasar a ejercer

ningún indicio en este sentido». Y añade que en este poema «el poeta evoca la obra mayor de este escritor: Bruges-la-morte, cuya edición es de 1892, con ilustraciones del pintor belga Fernand Knopff». Parece que Darío nunca visitó Brujas (1997: 5). 
una llamada a la complicidad masculina en los versos finales del apartado: «Mi ditirambo brasileño es ditirambo / que aprobaría tu marido. Arcades ambo»; esta última una expresión latina que, procedente de Virgilio, suele usarse para indicar que dos personas tienen caracteres o intereses comunes. Como se puede observar, los versos del apartado están llenos de una incisiva sugerencia irónica hacia sí mismo y la actividad desarrollada en la Conferencia Panamericana.

La segunda parte continúa el tema brasileño tomando como desarrollo las varias experiencias, algo que plasma mediante enumeraciones («ese Brasil maravilloso, / $\tan$ fecundo, $\tan$ grande, $\tan$ rico, $\tan$ hermoso» $)^{3}$ o con versos paralelísticos y anafóricos que denotan los placeres, pero también sus contrarios, el trabajo en la reunión y la presencia de uno de los personajes más conspicuos, Nabuco, Joaquim Nabuco (1849-1910), embajador de Brasil en EEUU que presidió la conferencia y fue activo defensor del panamericanismo. En esta enumeración el autor combina varias percepciones y sugiere momentos de agradable estancia ( «a pesar de Tijuca y del cielo opulento») y otros menos gratos que rememoran las discusiones de los delegados panamericanos. El tono irónico se percibe incluso en la desacostumbrada rima del alejandrino que rompe el verso con encabalgamientos abruptos («a pesar de Nabuco, embajador, y de / los delegados panamericanos que / hicieron lo posible por hacer cosas buenas»). Placeres y trabajo traen su consecuencia: «saboreé lo ácido del saco de mis penas; / quiero decir que me enfermé». Es entonces cuando en los versos que siguen se abre un paréntesis reflexivo en el que, de nuevo, con versos paralelísticos y anafóricos da cuenta de su enfermedad, para intentar explicar ese presente en los antecedentes de su vida, dados al placer de la comida y la bebida, unidos al carácter de su inserción en la sociedad del momento que exigía un gran esfuerzo mental como propio del mundo moderno que se afianzaba. Ello nos configura a ese sujeto poético que cuenta y que es él mismo, como el ejemplo de un hombre marcado por el mal del siglo xx:

quiero decir que me enfermé. La neurastenia es un don que me vino con mi obra primigenia.

¡Y he vivido tan mal, y tan bien, cómo y tánto!

¡Y tan buen comedor guardo bajo mi manto!

¡Y tan buen bebedor tengo bajo mi capa!

¡Y he gustado bocados de cardenal y papa!...

3. Para la relación del poema con Brasil, véase Sales de Souza (2012); y sobre todo Fernández (2012) donde se hace alusión al viaje de los diplomáticos y del propio Darío a Río de Janeiro a través de su crónica «La conferencia de Río de Janeiro», La Nación, 28 de julio de 1906, y su relación con los literatos de Brasil. 


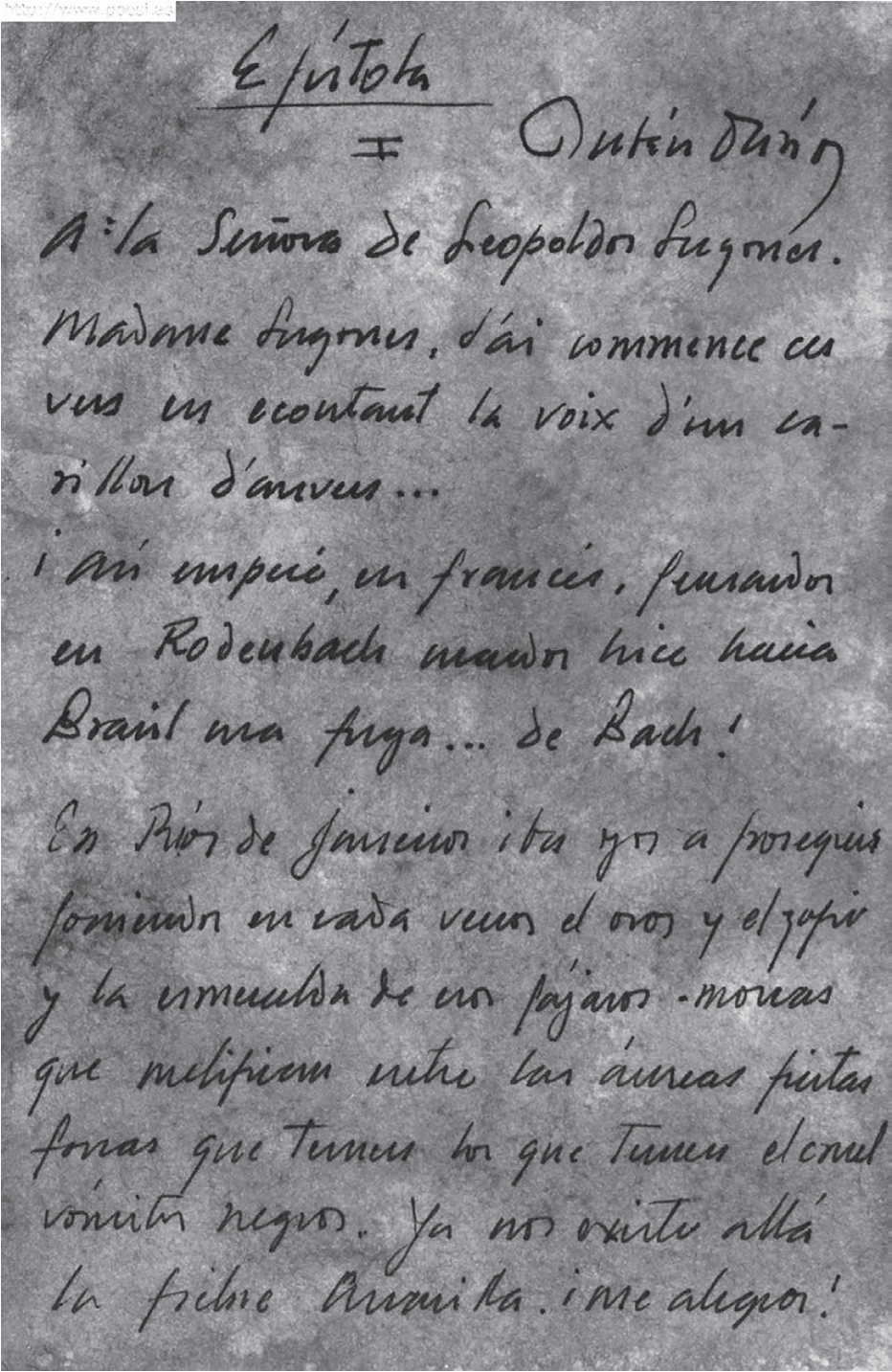

Anales, 28 (2016), pp. 251-267 


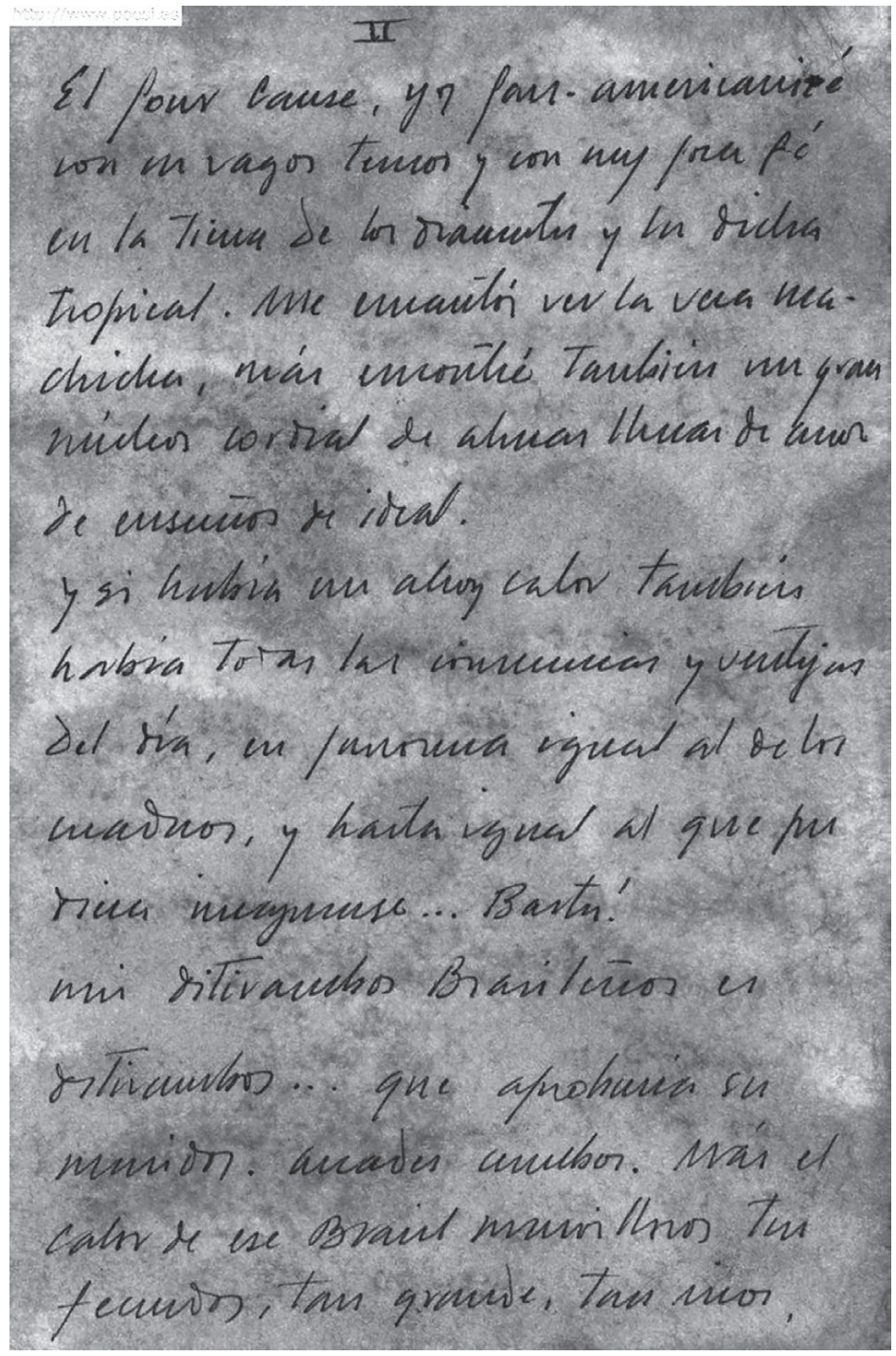

Original manuscrito: Epístola a la señora de Leopoldo Lugones. Rubén Darío.

Anales, 28 (2016), pp. 251-267 
Si las epístolas clásicas ponderaban el aurea mediocritas, esta autoexploración del poeta nicaragüense se explaya en su contrario con una intencionalidad transgresora, pues abundan las referencias irónicas a esa modernidad implacable que hace inviable la recuperación del cuerpo y del alma. La época moderna ha puesto el cuerpo de los ciudadanos en manos de los médicos y científicos que hacen diagnósticos para aconsejar remedios imposibles en ese mundo en el que rige la máquina, al recetar la retirada al campo, la vida saludable y deportiva, todo lo que choca con un mundo dominado por el dinero, algo que vuelve a ser comentado de forma irónica y coloquial: «¡Bravo! Si. Bien. Muy bien. ¿Y La Nación? / ¿Y mi trabajo diario y preciso y fatal?» así, con estas expresiones entrecortadas propias de la conversación e incidiendo en el énfasis que producen las dos conjunciones coordinadas que unen los adjetivos preciso y fatal. Son versos en los que se transparenta esa obligatoriedad de profesionalizarse en el mundo moderno, una observación que ya realizó Ángel Rama, respecto a los poetas modernistas, cuando expresa que «la exigencia que los llevaba al periodismo no era vocacional sino de orden económico, debido a que su sociedad no necesitaba de poetas pero sí de periodistas» (68) y respecto a Rubén Darío en concreto:

Rubén Darío fue toda su vida periodista. De la prensa, mucho más que de los cargos diplomáticos, obtuvo sus recursos económicos permanentes y a la vez ella fue el portavoz de su obra crítica y de su fama poética. Periodista en todos los países que visitó, conociendo antes las redacciones que las calles de la ciudad a la que llegaba; periodista forzado de gacetilla diaria o de crónica semanal, según los periódicos (69).

Por eso se añaden otros versos de irónicas observaciones: «Es preciso que el médico que eso recete, dé / también libro de cheques para el Crédit Lyonnais». Y rematan el apartado tres versos que redundan en ese espacio que ocupa el poeta, como ciudadano moderno, que debe acudir al banco o al automóvil como medios propios de esa civilización que en el fondo origina tedio en el hombre arrancado de sus valores más humanos: «en el cual pasee mi egregio aburrimiento / harto de profilaxis, de ciencia y de verdad».

La tercera parte del poema (47 versos) vuelve a repetir la misma alternativa arrastrando algunas imágenes de la conferencia panamericana. Y lo hace aludiendo a Elihu Root (1845-1939), el secretario de estado norteamericano que realiza el viaje de Nueva York a Brasil en el barco Charleston, al que irónicamente Darío llama “Charleston sagrado». La llegada a Buenos Aires es considerada como una vuelta a casa aunque es consciente de no haber guardado la convalecencia de su enfermedad. Es un dato conocido que Darío acude a un banquete de homenaje que realiza La Nación. El poeta exalta el ambiente 
favorable de la ciudad porteña en la que se siente cómodo después de haber vivido algunos años en el pasado, le gusta su cosmopolitismo y el gozo de los placeres de la gran ciudad. Es evidente que el verso «y mis viejas siringas con su pánico estruendo» es una referencia a los versos de Prosas profanas (1896) que concibió y publicó en la ciudad bonaerense. Es decir, Darío expresa el disfrute de ese presente halagüeño pero también alude al pasado que ya es irrecuperable. Hacia el verso 12 la epístola da un quiebro en su itinerario marcando el nuevo cruce del océano hacia París. Este espacio está marcado, más que el de Buenos Aires, por frases negativas que delinean a la capital del mundo, la ciudad inclemente, más moderna y cosmopolita que Buenos Aires, y también más dañina para el ciudadano: «Me volví al enemigo / terrible, centro de la neurosis, ombligo / de la locura, foco de todo surmenage». Ese papel de sauvage al que se alude hace referencia a la soledad que entraña toda gran ciudad y a la vez a la dificultad de guardar la propia vida, desarrollando la obra proyectada sin tener que cuidarse de intromisiones. Es esta la parte más confesional de la epístola pues Darío vuelca en estos versos la vida asediada por las intrigas, las miserias, las ingratitudes y las traiciones para trazar las notas más destacadas de su carácter, su sentimentalismo, su ingenuidad, tan poco válidos en un mundo de intrigas e egoísmos, su carácter visionario y su ideal de vida, amante de las cosas poco prácticas, mal calculador, fácil presa de cualquier truhán, pero a la vez con capacidad para saborear el lujo y el placer, muy distante de la aurea mediocritas:

Que ando, nefelibata, por las nubes... Entiendo.

Que no soy hombre práctico en la vida... ¡Estupendo!

Sí, lo confieso: soy inútil. No trabajo por arrancar a otro su pitanza; no bajo

a hacer la vida sórdida de ciertos previsores.

Yo no ahorro ni en seda, ni en champaña, ni en flores.

No combino sutiles pequeñeces, ni quiero

quitarle de la boca su pan al compañero.

$\mathrm{Al}$ confesar esos gustos por la elegancia y por las gentes aristocráticas, se deduce como consecuencia que se siente obligado a conseguir el dinero necesario para disponer su vida dentro de esas pautas. En este mundo moderno solo el dinero rige la sociedad, y de ello es consciente el poeta en sus confidencias. Sabe que debe trabajar e implicar, nueva ironía, a tres elementos en estado líquido que cooperan a ese objetivo: «el sudor de mi alma, de mi sangre y mi tinta». Una manera expresiva de aludir a su profesión, la de periodista, en este caso corresponsal de La Nación de Buenos Aires, con la que se gana la vida. 


\section{Mallorca, la isla paradisíaca}

Las partes IV, V y VI van a situarse en la isla de Mallorca, pero el primer verso del apartado IV traza de nuevo el recuerdo del viaje: «Tal continué en París lo empezado en Anvers. / Hoy, heme aquí en Mallorca, la terra dels foners». Las referencias culturales de autores y lugares de Mallorca constituyen un verdadero homenaje a la isla y a la vez se erigen en una de las más exactas descripciones de la zona en aquellos años. Advertimos que empieza con un homenaje a un autor catalán, «Mossen Cinto», que es Jacinto Verdaguer (1845-1902), en el que ha leído la expresión que cita, terra dels foners, o lo que es lo mismo «la tierra de los honderos» que fueron los habitantes primitivos de la isla ${ }^{4}$. En este momento advertimos que Darío toma nuevo impulso al referirse de forma expresa a la destinataria de la epístola, en una nueva salutatio que es ahora también una ofrenda: «Y desde aquí señora, mis versos a ti van, / olorosos a sal marina y azahares, / al suave aliento de las islas Baleares». Esta parte cuarta consta solo de 14 versos y tras la nueva referencia a la destinataria, se encauza el sentido para describir el entorno de la isla y su paisaje: el azul, el oro del sol, la alegría que dan las flores, la tranquilidad del mar y las barcas de los pescadores, un mundo idílico en el que no cabe la corrupción del mundo moderno. Se advierte que el culturalismo de Darío le lleva a establecer una comparación con el mundo clásico, cosa más frecuente en la época precedente, pero de la que no se libera nunca; así compara el mar mallorquín con el Partenopeo, es decir el que está en torno a Nápoles. Los versos finales de esta parte describen su alojamiento paradisiaco en su villa, situada entre el monte y el mar con abundantes flores que ofrecen paz y serenidad. Aparte de que esta descripción de la isla de Mallorca se ajusta bien a la realidad del mundo latino y mediterráneo, también corresponde al tópico del lugar paradisíaco, pues remite a la placidez de lo estático, alcanzado por fin después de la enfermedad y en la huida del dinamismo desasosegante del mundo moderno.

La quinta parte continúa con la descripción del mismo entorno, ahora el poeta no viaja, sino pasea, y le confía a su interlocutora cómo es ese lugar plácido en el que piensa recuperarse. El apartado que consta de 40 versos, se divide a su vez en dos partes diversas, la descripción costumbrista, romántica y exotista del mercado de la Plaza Mayor de la ciudad y la reflexión laudatoria sobre Raimundo Lulio que "De los hondos espíritus es de mis preferidos"5.

4. Ya en su crónica inicial de España contemporánea (1901), «En Barcelona», Darío se refiere por extenso para los lectores de La Nación a la cultura y la historia catalana (Darío, 2003: 44-54).

5. En la primera versión de la epístola, aparecida en el Lunes de El Imparcial, esta parte referida a Raimundo Lulio ofrecía diez versos más suprimidos después (Díez Canedo: 94). 
La descripción no está exenta de humor, como la interpelación que se hace a si mismo introduciendo una referencia a Coppée en el segundo verso ("Qué Coppée, no es verdá») con el que viene a ironizar con la obra del autor francés al que Darío admiraba hacía muchos años; François Coppée (1842-1908), fue autor de una poesía de lo cotidiano y de lo humilde para lo que esgrimió también el prosaísmo. Siguiendo esta pauta descriptiva Darío elabora una panorámica de esa muchedumbre de vendedores de viandas de todo tipo, describe a las mujeres de Mallorca y a las aldeanas que venden en el mercado en sus atuendos y su físico; son mujeres que nada tienen que ver con las mujeres modernas de la gran ciudad. Aunque Darío es consciente de que su descripción procede de una limitada experiencia, y por eso dirá con humor que esas mujeres llevan falda, pañuelo y trenza, aunque concede: «Esto, las que yo he visto, al pasar, por supuesto. / Y las que no la lleven no se enojen por esto». Incluso introduce una expresión en mallorquín: «Y saludan con un bon dia tengui gracioso» para amalgamar una enumeración que no solo describe el mercado, sino que recurre a la abundancia característica del lugar paradisíaco: «patatas y coles, / pimientos de corales, tomates de arreboles, / sonrosadas cebollas, melones y sandías, / que hablan de las Arabias y las Andalucías». Termina con una referencia culta a dos escritores, Madame de Noailles (18761933) y Francis James (1868-1938), para los que considera que tal efusión de productos del campo serían buenos temas de sus versos.

La segunda parte de este apartado quinto es una especie de evocación que se produce en medio de esta plaza del mercado. Así se figura estar ante la casa en que nació uno de los autores que más admiraba del mundo catalán, Raimundo Lulio (c.1232-1315), místico y filósofo reconocido de la antigüedad, al que Darío llama «mallorquín de hierro», «mallorquín de oro», identificándolo con la propia isla, recordemos los títulos en prosa La isla de oro (1907) y El oro de Mallorca (1913): «De los hondos espíritus es de mis preferidos. / Sus robles filosóficos están llenos de nidos / de ruiseñor. Es otro y es hermano del Dante». Las frases exclamativas que vienen a continuación inciden en la misma idea de exaltar esa admiración y justificarla. Acerca de la figura de Raimundo Lulio evocada por Darío, Enrique Díez Canedo reproduce un párrafo de Gabriel Alomar (1873-1941) que es pertinente traer aquí, pues tras destacar que los versos de Darío acerca de su figura «valen más que toda la precedente poetización de aquella figura», recuerda que esos versos tal y como aparecen en El canto errante «han sufrido una merma inexplicable. Cuando el gran poeta me los leyó en una noche inolvidable, y tal como fueron publicados, según creo, en Los Lunes de El Imparcial, tenían en el fragmento luliano una extensión mayor. Los versos que faltan en la edición corriente no 
merecen esa omisión» (Díez Canedo, 92). Advirtamos además que esos versos que aparecen en la versión primitiva al final de esa parte quinta se abren con una nueva invocación o petitio benevolentiae a la interlocutora que ahora aparece con su nombre real: «Excúsame, si quieres, oh Juana de Lugones, / Estas filosofías llenas de digresiones. / Mas que pasión por Ramón Llull es pasión vieja / perfumada de siglos, de verso y de conseja» (Díez Canedo: 94).

La sexta parte enlaza ahora con el tema mallorquín, es decir, ya se ha abandonado el tema del viaje y ahora el enlace se establece con el mismo paisaje que se contempla: el aire, el ambiente, el temporal, los yates que entran en la rada de Porto-Pi y que resume con un solo verso: «Vista linda: aguas bellas, luz dulce y tierra fresca». Pero por otro lado introduce otra vez la salutatio a la interlocutora que reviste del tópico de la vida retirada, deseando el apartamiento para siempre en estos lugares «para poder venir a hacer su vida entera / en esta luminosa y espléndida ribera». Tras una pausa da comienzo al recuerdo de los célebres huéspedes que en el pasado o en el presente residen en la isla, así recuerda que «Hay no lejos de aquí un archiduque austriaco» en evidente alusión al archiduque Luis Salvador de Austria (1847-1915) que vivió los últimos años de su vida en la residencia del monasterio de Valldemosa, como también recuerda la estancia de George Sand y Federico Chopin en la misma Cartuja. En efecto, esta tuvo lugar de noviembre de 1838 a febrero de 1839. Las confidencias de Darío en la carta que dirige a la señora de Lugones son, en esta parte, curiosas, por un lado alaba al archiduque y lo compara elogiosamente con Jean Orth (1852-1890) como protector de las artes y las letras, por otro también elogia a Santiago Rusiñol (1861-1931), uno de los artistas catalanes que más admiraba y con el que tenía una mayor afinidad, en cambio la historia de la estancia de George Sand y Chopin es presentada con humor no exento de ironía: «Ignoro si vino aquí con Musset, / y si la vampiresa sufrió o gozó, no sé». Una llamada al final de este verso corrige la travesura del poeta que necesitaba el nombre de Musset para guardar la rima y corrige en dos versos en nota: «He leído ya el libro que hizo Aurora Dupin. / Fue Chopin el amante aquí ¡Pobre Chopin!».

Como se puede apreciar este apartado es el más largo, consta de 58 versos que además están distribuidos en estrofas desiguales que acotan el cambio de los temas, pues esta es la parte más reflexiva. En efecto, después de las cuatro estrofas iniciales que dedica a los temas citados, en el verso 29 da comienzo a otra estrofa en la que traza la añoranza de la utópica estancia en la isla paradisíaca. Es un apartado en el que hay imágenes y referencias a su vida y a su obra: «¿Por qué mi vida errante no me trajo a estas sanas / costas antes de que las prematuras canas / de alma y cabeza hicieran de mí la mezcolanza / 
formada de tristeza, de vida y esperanza». Versos en los que se aprecia el tono meditativo y metafísico de los versos precedentes de Cantos de vida y esperan$z a$ (1905), y también la alusión al mundo griego de Prosas profanas, pero es aquí el libro madrileño de 1905 el más presente, porque encarna el declive de su vida, y tanto, que en dos ocasiones repite en los versos su título: «de vida y esperanza» $\mathrm{y}$ «mis vidas y esperanzas». Otra estrofa, más corta, de solo cuatro versos viene a incidir en el tema del tempus fugit y el ubi sunt que se introducen por las preguntas retóricas: «¿dónde está aquel templo de mármol», «Dónde los hombre ágiles que las piedras redondas / recogían para los cueros de sus hondas?...». Como se observa, dos versos hacen referencia a su propia vida personal y otros dos a la prehistoria de la isla a sus célebres foners u honderos de los que habló más arriba. Y es que en la estrofa que viene a continuación, tras un nuevo recordatorio de la interlocutora («Calma, calma. Esto es mucha poesía, señora»), se rompe la imagen del locus amoenus para ingresar la fractura de los tiempos modernos a través de las siluetas de los barcos que llegan a Mallorca de Valencia, Marsella, Barcelona y Génova para comentar: «La ciencia / comercial es hoy fuerte y lo acapara todo». La isla de Mallorca, por aquella época ya está perdiendo ese carácter de lugar totalmente idílico. Como siempre los versos finales vuelven a ser irónicos y hasta sarcásticos ante ese progreso del mundo que todo lo subvierte, y el sujeto poético aprovecha el tonificante aire marino para concluir: «como Kant y como el asno, pienso. / Es lo mejor», nueva frase irónica y hasta sarcástica que equipara al gran filósofo con el asno de la fábula, usando para más ironía la doble significación de la palabra pienso (del verbo pensar y el sustantivo, comida para animales).

La conclusión o parte séptima de la epístola, tan breve que solo consta de seis versos, contiene una despedida y una petición, aparte de resumir el contenido principal de la misiva en un único verso: «Si hay, he dicho, señora, alma clara, es la mía». Es como si esa claridad de espíritu se potenciara en la isla y se hiciera más consecuente la petición a los amigos: "Mírame transparentemente, con tu marido, / y guárdame lo que tú puedas del olvido". Este final contiene para algún crítico ${ }^{6}$ la clave de lo que significa toda carta: el establecimiento de la memoria, la búsqueda de la amistad perdurable que traspase el tiempo y el olvido.

\section{Una forma y un ritmo trasgresores}

Las epístolas clásicas solían escribirse en endecasílabos, así lo hizo Garcilaso, por ejemplo, en la famosa «Epístola a Boscán» en endecasílabos blancos.

6. Hace esta reflexión Gonzalo Sobejano (36).

Anales, 28 (2016), pp. 251-267 
Aunque el metro más frecuente era el terceto encadenado, los autores españoles introdujeron otros modelos estróficos, silvas, romances endecasílabos o versos sueltos ${ }^{7}$. Darío incluyó cuatro epístolas en su libro de 1885, Epístolas y poemas, «A Ricardo Contreras», «A Juan Montalvo», «A Emilio Ferrari» $\mathrm{y}$ «Erasmo a Publio», la primera está escrita en tercetos encadenados, la segunda y la cuarta en endecasílabos blancos y la tercera en sextetos asonantes de heptasílabos y endecasílabos ${ }^{8}$.

En el caso que nos ocupa Darío utiliza un metro en principio poco apropiado para el cometido, lo que suponía un enorme reto. Ya se ha indicado que la razón por la cual eligió los versos alejandrinos pareados reside en que su amigo, Leopoldo Lugones, utilizó el mismo metro en su poema de $1903^{9}$, a lo que nos hemos referido en el apartado anterior, es decir esta epístola entraba en el juego amistoso entre los dos autores. El poema de Lugones no resulta tan acertado como el de Darío en su construcción formal, quizá porque el nicaragüense se evade de la solemnidad de la epístola y potencia la frase conversacional combinada con el manejo del alejandrino, de cuya composición surge un juego musical y prosaico al mismo tiempo. Si revisamos el poema nos encontramos con curiosos efectos rítmicos, no solo por la frecuencia de la anáfora y de los paralelismos, sino por el uso de las rimas, notablemente atrevidas que solo Darío podía llevar a cabo por esa época. Díez Canedo recuerda que

aquella Epístola fue piedra de escándalo en los menudos corrillos madrileños. El verso que dice: «Los delegados panamericanos que», se citaba entre risas como prueba de la torpeza de Rubén Darío para versificar. No fueron muchos los que entonces vieron la magistral ironía de la forma, la constante vena del riquísimo caudal de poesía que iba fluyendo de parte a parte en aquellos versos de Rubén (93).

Al comentar el poema Susana Zanetti destaca cómo Darío vuelve a su verso predilecto pero lo quiebra y lo presiona, «ahogando las posibilidades sonoras armoniosas de antaño, con finales de rima insólitos y rudos encabalgamientos», lo que lleva a este poema autobiográfico a una «continuidad forzada, a tropezones, que habla del desasosiego ante un deambular, un peregrinaje que parece alcanzar sentido solo en lo fragmentario, en los trabajos y los días del artista asediado por la pérdida del reino» (132-133). En efecto, la rima es un condicionamiento fundamental en el poema, al utilizar el pareado de un

7. Para un estudio de la epístola clásica: López Bueno, 2000.

8. Véase mi trabajo (Ruiz Barrionuevo: 106-108).

9. Es conocida la obsesión que Lugones padecía por la rima, véase el "Prólogo" a Lunario sentimental donde afirma que la rima es esencial en el verso moderno (194-195). 
verso largo como estructura formal, y ello asoma desde el comienzo, cuando los cuatro versos iniciales riman, los primeros en francés (vers- Anvers) y los segundos en español, con una isotopía que produce un efecto irónico y desdeñoso (Rodenbach-Bach). Posteriormente muchas de estas rimas inciden en el tono conversacional y en la ironía que a veces se desplaza hasta el sarcasmo. En la imposibilidad de hacer una lectura de la incidencia de todas estas rimas, destaquemos algunas, muy especialmente las que producen encabalgamiento abruptos al extremo, y que Darío había ensayado ya en alguna ocasión en su libro precedente, Cantos de vida y esperanza. En la misma parte primera aparece: «en panorama igual al de los cuadros y hasta / igual al que pudiera imaginarse... Basta». En la segunda parte: «a pesar de Nabuco, embajador, y de / los delegados panamericanos que / hicieron lo posible por hacer cosas buenas / saboreé lo ácido del saco de mis penas». Otro ejemplo en el mismo apartado: «con las alondras y con Garcilaso, y con / el sport. ¡Bravo! Sí. Bien. Muy bien. ¿Y La Nación?». En el apartado tercero tenemos otro ejemplo: «Por eso los astutos, los listos, dicen que / no conozco el valor del dinero. ¡Lo sé!». En el apartado sexto: «El temporal no deja que entren los vapores. Y / un yach de lujo busca refugio en Porto-Pi», y un poco más adelante: «iAh, señora, si fuese posible a algunos el / dejar su Babilonia, su Tiro, su Babel».

Uno de los aciertos del poema son las formas coloquiales y la inclusión de expresiones francesas, que eran frecuentes en un medio en el que este idioma era imprescindible. También aparecen términos en latín, en inglés y en mallorquín. Todas son encajadas de forma natural y magistral en los versos alejandrinos: «Et pour cause. Yo pan-americanicé / con un vago temor y con muy poca fe»; «Mi ditirambo brasileño es ditirambo / que aprobaría su marido. Arcades ambo» (Parte I); «Es preciso que el médico que eso recete, dé / también libro de cheques para el Crédit Lyonnais» (Parte II); «ombligo / de la locura, foco de todo surmenage / donde hago buenamente mi papel de sauvage» (Parte III); «Hoy, heme aquí en Mallorca, la terra dels foners» (Parte IV); «Y saludan con un bon dia tengui gracioso» (Parte V); pero con todo, en estos apartados dedicados a Mallorca «se serena la discordancia entre sintaxis y rima» (Zanetti, 148). Gran parte de estas expresiones coadyuvan a ese cosmopolitismo del mundo contemporáneo en que está situado el poema, que es el mismo que el propio autor vivía. Por otro lado son sorprendentes las frases entrecortadas que preludian las percepciones yuxtapuestas, que en un intento de presentar la vida en toda su riqueza, plasman los poetas en la vanguardia. El texto fragmentario, balbuciente y sugerente, asoma en versos como: «el sport. ¡Bravo! Sí. Bien. Muy bien. ¿YY La Nación?» (Parte II); «Que ando, nefelibata, por las nubes... Entiendo. / Que no soy hombre práctico en 
la vida... ¡Estupendo!» (Parte III); «A veces me dirijo al mercado, que está / en la Plaza Mayor. (¿Qué Coppée, no es verdá?)» (Parte v). Insistamos que este coloquialismo está trabajado en alejandrinos pareados y que, contrariamente a lo que pudiera pensarse, producen una especial sonoridad de confidencia irónica que nos revierte la propia imagen del poeta con su errante vivir y que se vuelca en la confidencia de un corresponsal a otro: «La mejor epístola poética: una persona escribe a otra, en verso y en confianza, cómo pasa la vida» (Sobejano, 17). Es evidente que esta epístola, tan trasgresora, sin embargo cumple como ninguna el precepto básico de la comunicación en confianza de dos interlocutores. Claro que hay que contar que tras la figura de la señora de Lugones estaba también la persona del amigo, el poeta argentino Leopoldo Lugones.

En resumen, Darío culmina en este texto el único modelo de epístola posible y que hoy nos interesa, una epístola vinculada a sus propias vivencias, un texto que admite la confidencia y el desorden mismo del fluir de la vida, una misiva que trata de aproximar a dos seres aunque en este caso el lector irrumpa como transgresor esperado y necesario de ese monólogo transmitido a la destinataria. Por otro lado la poesía de Darío en este caso avanza hacia formas del siglo XX en las que se rompe el hermetismo al implantar un tono conversacional que aparecería en la segunda mitad del siglo XX acompañado del humor y la ironía (Alemany 73-76). Lo que importa es que al entrar en comunicación con el lector, aunque se requiere el modelo interpuesto de la epístola literaria, se anticipa la poesía del futuro.

\section{Bibliografía citada}

Alemany Bay, Carmen, Poética coloquial hispanoamericana, Alicante, Universidad de Alicante 1997.

CARILla, Emilio, Una etapa decisiva de Darío (Rubén Darío en la Argentina), Madrid, Gredos, 1967.

DARío, Rubén, Autobiografía, en Obras Completas, Madrid, Afrodisio Aguado, 1959, tomo I, p. 17- 177.

- Poesía, prólogo Ángel Rama, ed. Ernesto Mejía Sánchez, Cronología Julio Valle Castillo, Caracas, Biblioteca Ayacucho, 1977.

- España Contemporánea, edición de Noel Rivas Bravo, Ed. Renacimiento, Sevilla, 2003.

DíEz CANEDO, Enrique, «Otras notas acerca de Darío. Una digresión de Alomar y unos versos de Darío», en Letras de América, México, El Colegio de México, 1944, pp. 92-95. 
FERNÁNDEZ, Juan Manuel, «Rubén Darío. Una obnubilaçâo brasílica», Caracol, 3 (2012), 102-133.

Gullón, Ricardo, El modernismo visto por los modernistas, Barcelona, Labor, 1980.

LÓPEZ BuENO, Begoña (ed), La epístola, Universidad de Sevilla, 2000.

LuGONES, Leopoldo, Obras poéticas completas, Madrid, Aguilar, 1959.

RAMA, Ángel, Rubén Darío y el modernismo. Circunstancia socioeconómica de un arte americano, Caracas, Universidad Central de Venezuela, 1970.

RUIZ BARRIONUEVO, «La epístola y Rubén Darío», Formes breves de l'expression culturelle en Amérique Latine de 1850 a nos jours, en América, Cahiers du CRICCAL, Paris, Presses de la Sorbonne Nouvelle, 19, (1997), pp. 105-113.

SALES DE SOUZA, Ismênia, «Rubén Darío y el país maravilloso de Brasil» en Hipertexto, 16 (2012), pp. 168-172.

SobejANO, Gonzalo, «Lope de Vega y la epístola poética» en Manuel García Martín ed., Estado actual de los estudios sobre el Siglo de Oro», Salamanca, Acta Salmanticensia, 1993, vol. 1, pp. 17-36.

VALEMBOIS, Víctor, «Rubén Darío, catalizador intercultural (más sobre su estancia en Bélgica)» en Romaneske, Vereniging van Leuvense Romanisten, 22, 4 (1997) <http://www.vlrom.be/pdf/974rubendario.pdf > [consulta: 18 junio, 2016].

ZANETTI, Susana, «Rubén Darío, cosmopolitismo y errancia: Epístola a la Señora de Leopoldo Lugones», CELEHIS. Revista del Centro de Letras Hispanoamericanas, Actas del III Congreso Internacional CELEHIS de Literatura Española, Latinoamericana y Argentina, 17, 19, (2008), pp. 131-158. 